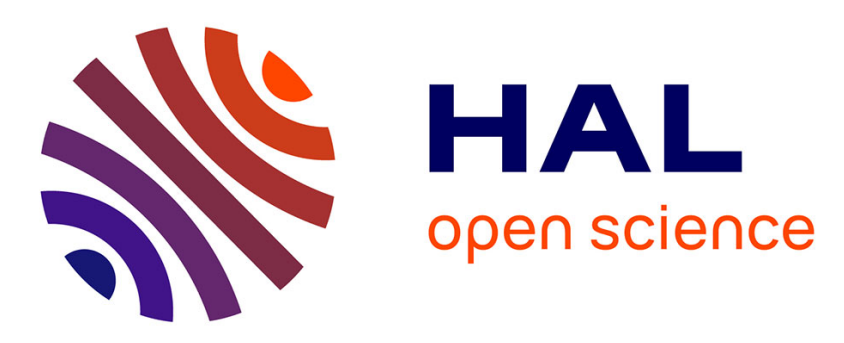

\title{
Influence of microalgae cell wall characteristics on protein extractability and determination of nitrogen-to-protein conversion factors
}

Carl Safi, Michael Charton, Olivier Pignolet, Françoise Silvestre, Carlos Vaca-Garcia, Pierre-Yves Pontalier

\section{To cite this version:}

Carl Safi, Michael Charton, Olivier Pignolet, Françoise Silvestre, Carlos Vaca-Garcia, et al.. Influence of microalgae cell wall characteristics on protein extractability and determination of nitrogen-toprotein conversion factors. Journal of Applied Phycology, 2013, 25 (2), pp.523-529. 10.1007/s10811012-9886-1 . hal-02064796

\section{HAL Id: hal-02064796 https://hal.science/hal-02064796}

Submitted on 12 Mar 2019

HAL is a multi-disciplinary open access archive for the deposit and dissemination of scientific research documents, whether they are published or not. The documents may come from teaching and research institutions in France or abroad, or from public or private research centers.
L'archive ouverte pluridisciplinaire HAL, est destinée au dépôt et à la diffusion de documents scientifiques de niveau recherche, publiés ou non, émanant des établissements d'enseignement et de recherche français ou étrangers, des laboratoires publics ou privés. 


\section{Open Archive Toulouse Archive Ouverte (OATAO)}

OATAO is an open access repository that collects the work of Toulouse researchers and makes it freely available over the web where possible

This is an author's version published in: http://oatao.univ-toulouse.fr/23265

Official URL: https://doi.org/10.1007/s10811-012-9886-1

\section{To cite this version:}

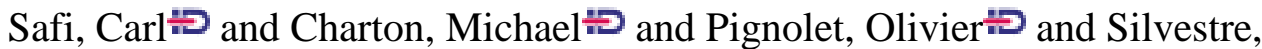

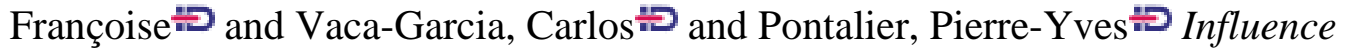
of microalgae cell wall characteristics on protein extractability and determination of nitrogen-to-protein conversion factors. (2013) Journal of Applied Psychology, 25 (2). 523-529. ISSN 0921-8971

Any correspondence concerning this service should be sent to the repository administrator: tech-oatao@listes-diff.inp-toulouse.fr 


\title{
Influence of microalgae cell wall characteristics on protein extractability and determination of nitrogen-to-protein conversion factors
}

\author{
Carl Safi • Michaël Charton • Olivier Pignolet • \\ Françoise Silvestre • Carlos Vaca-Garcia • \\ Pierre-Yves Pontalier
}

\begin{abstract}
Additional evidence about the influence of the cell wall physical and chemical characteristics on protein extractability was determined by calculating the conversion factors of five different microalgae known to have different cell wall composition, and their protein extracts. The conversion factors obtained for crude rigid cell walled Chlorella vulgaris, Nannochloropsis oculata and Haematococcus pluvialis were $6.35,6.28$ and 6.25 , respectively, but for their protein extracts the values were lower with 5.96, 5.86 and 5.63. On the other hand, conversion factor obtained for fragile cell walled microalgae Porphyridium cruentum and Athrospira platensis was 6.35 for the former and 6.27 for the latter, with no significant difference for their protein extract with 6.34 for the former and 6.21 for the latter. In addition, the highest hydro-soluble protein percentage recovered from total protein was for $P$. cruentum $80.3 \%$ and A. platensis $69.5 \%$ but lower for $C$. vulgaris with $43.3 \%, N$. oculata with $33.3 \%$ and $H$. pluvialis with $27.5 \%$. The study spotted the light on the influence of the cell wall on evaluating the conversion factor and protein extractability. In addition, it showed the necessity of finding the conversion factor every
\end{abstract}

\footnotetext{
C. Safi $(\bowtie) \cdot$ M. Charton $\cdot$ O. Pignolet $\cdot$ F. Silvestre $\cdot$

C. Vaca-Garcia $\cdot$ P.-Y. Pontalier

INP-ENSIACET, Laboratoire de Chimie Agro-industrielle (LCA),

Université de Toulouse,

31030 Toulouse, France

e-mail: carl.safi@ensiacet.fr

C. Safi $\cdot$ M. Charton $\cdot$ O. Pignolet $\cdot$ F. Silvestre $\cdot$ C. Vaca-Garcia $\cdot$

P.-Y. Pontalier

INRA, UMR 1010 CAI,

31030 Toulouse, France
}

time accurate protein quantification is required, and proved that there is not a universal conversion factor that can be recommended.

Keywords Amino acid profile $\cdot$ Cell wall $\cdot$ Conversion factor $\cdot$ Nitrogen $\cdot$ Protein extract

\section{Introduction}

Microalgae have been consumed long time ago by the Aztecs and other Mesoamericans who used this biomass as an important food source (Vonshak 1997). Nowadays, in Japan for instance, Chlorella vulgaris is added to food such as noodles and pasta (Fradique et al. 2010) to improve the nutritional quality of the meal.

Microalgae are gaining interest due to their capacity to accumulate important amounts of multiple components (proteins, lipids, carbohydrates and pigments) compared to any other sources, and therefore protein content is considered as one of the cardinal components determining their nutritional value. For instance, Arthrospira (Spirulina) maxima can accumulate proteins up to $71 \%$ dry weight (Becker 1994). Thus, analysing and quantifying the protein content are key factors that should be thoroughly investigated. A capital point is to calculate precisely the nitrogen-to-protein conversion factor (NTP). While the standard value of 6.25 is used, Kjeldahl or elemental analysis may lead to an overestimation or underestimation of the protein quantity. Moreover, these two methods take into account the totality of the nitrogen present in the biomass from which 59-98 \% (Lourenço et al. 1998; Fujihara et al. 2001; Lourenço et al. 2004; Gonzalez 
Lopez et al. 2010) of total nitrogen belongs to protein and the rest comes from pigments, nucleic acids and other inorganic components. It is true that the colorimetric method of Lowry (Lowry et al. 1951) is an accurate method for protein quantification (Peterson 1979; Gonzalez Lopez et al. 2010) and it does not require a conversion factor. Nevertheless, this method determines only the hydrosoluble proteins (Crossman et al. 2000; Diniz et al. 2011) and not the total protein content.

In addition, the extraction of proteins can be diminished by the cell wall barrier, which can prevent the solubilisation of all the intracellular proteins affecting thus the value of the nitrogen-to-protein conversion factor. Therefore, the impact of the cell wall characteristics on protein extractability should be taken into account and analysed in order to prevent an incorrect estimation of the protein content.

Multiple studies have focused on finding a method to recommend the right conversion factor; for instance, Gonzalez Lopez et al. (2010) focused on obtaining the conversion factor of five microalgae after breaking the cell wall, and then finding a correlation between protein content and total nitrogen content (elemental analysis or Kjeldahl). As a result, among five microalgae a new mean conversion factor was estimated to 4.44 (elemental analysis) and 5.95 (Kjeldahl). Another study (Lourenço et al. 2002) determined the conversion factor for 19 tropical seaweeds harvested directly from the beach; and in a second study (Lourenço et al. 1998), 12 marine microalgae were analysed under different growth phases and a mean value of 4.58 was found.

The following study assesses the impact of the cell wall on the protein extractability and the evaluation of the NTP for five microalgae intensively grown worldwide and having wide taxonomic diversity.

\section{Materials and methods}

The microalgae used are: the cyanobacterium Arthrospira platensis (strain PCC 8005), two Chlorophyceae C. vulgaris (strain SAG 211-19), Haematococcus pluvialis (unknown strain), one Rhodophyta Porphyridium cruentum (strain UTEX 161) and the Eustigmatophyceae Nannochloropsis oculata (unknown strain).

Each alga was cultivated in a different culture medium: Hemerick medium for $P$. cruentum, Sueoka medium for $C$. vulgaris, Basal medium for $H$. pluvialis, Conway medium for $N$. oculata, and Zarrouk medium for A. platensis. All were grown in batch mode in an indoor tubular air-lift photobioreactor (PBR, $10 \mathrm{~L}$ ) at $25{ }^{\circ} \mathrm{C}$ (Loubiere et al. 2011) after inoculation from a prior culture in a flat panel air-lift PBR (1 L). Culture mixing was by sterile air injection at the bottom of the PBR. The $\mathrm{pH}$ and temperature were recorded by a $\mathrm{pH} /$ temperature probe and $\mathrm{pH}$ was regulated at 7.5 with $\mathrm{CO}_{2}$. The algae were harvested during the exponential growth phase and concentrated by centrifugation, and then supplied as a frozen paste from Alpha Biotech (Asserac, France). The biomass contained $20 \%$ dry weight. The frozen paste of crude microalgae was freeze-dried in a Fisher Bioblock Scientific Alpha 2-4 LD Plus device (Illkirch, France).

\section{Protein extraction}

Stock solutions were prepared with approximately $500 \mathrm{~mL}$ of ultrapure water and some drops of $2 \mathrm{~N} \mathrm{NaOH}$ to adjust the solution to $\mathrm{pH} 12$. A sample of $1 \mathrm{~g}$ of freeze-dried biomass was added to $50 \mathrm{~mL}$ of stock solution. The mixture was heated to $40{ }^{\circ} \mathrm{C}$ with stirring for $1 \mathrm{~h}$ followed by centrifugation at $5,000 \times g$ for $10 \mathrm{~min}$. Samples were taken for analysis by the colorimetric method of Lowry et al. (1951), elemental analysis and amino acid analysis.

\section{Lowry method}

A calibration curve was prepared using a concentration range of bovine serum albumin from 0 to $1,500 \mu \mathrm{g} \mathrm{mL}^{-1}$. In order to measure the protein content, $0.2 \mathrm{~mL}$ of each standard or samples containing the crude protein extract were withdrawn and then $1 \mathrm{~mL}$ of modified Lowry reagent was added to each sample. Each sample was then vortexed and incubated for exactly $10 \mathrm{~min}$. After incubation, $100 \mu \mathrm{L}$ of Folin-Ciocalteu reagent $(1 \mathrm{~N})$ were added and again vortexed and incubated for exactly $30 \mathrm{~min}$. The absorbance was then measured at $750 \mathrm{~nm}$.

\section{Elemental analysis}

Total nitrogen of the freeze-dried biomass was evaluated using a PerkinElmer 2400 series II elemental analyser. Samples of $2 \mathrm{mg}$ were placed in tin capsules and then heated at $925^{\circ} \mathrm{C}$ using pure oxygen as the combustion gas and pure helium as the carrier gas, then evaluating the nitrogen percentage and converting it into protein percentage by using the conversion factors calculated for each microalga in this study.

Amino acid analysis and NTP calculation

The determination of the amino acid composition of the biomass was performed according to a widely used standard method (Moore and Stein 1948). The samples were hydrolysed with $6 \mathrm{~N}$ hydrochloric acid at $103{ }^{\circ} \mathrm{C}$ for $24 \mathrm{~h}$. Then, the hydrolysed material was adjusted to $\mathrm{pH} 2.2$ with $6 \mathrm{~N}$ $\mathrm{NaOH}$ and stabilised with a $\mathrm{pH} 2.2$ citrate buffer solution. The final solution was then filtered with $0.45 \mu \mathrm{m}$ PTFE 
membrane to remove any residual solids remaining in the solution. The analysis was performed by using an amino acid analyser Biochrom Ltd 32+ (Cambridge, UK) equipped with a high pressure PEEK "column+precolumn" (size, $200 \times 4.6 \mathrm{~mm}$ ) packed with Ultropac cation exchange resin containing sodium. The separation of amino acids is carried

out by elution with loading buffers (flow rate $25 \mathrm{~mL} \mathrm{~h}^{-1}$ ) at different $\mathrm{pH}$. After reaction with ninhydrin (flow rate $35 \mathrm{~mL} \mathrm{~h}^{-1}$ ), amino acids are detected with a UV detector at a wavelength of $570 \mathrm{~nm}$, with the exception of proline, for which detection occurs at $440 \mathrm{~nm}$. Calculation of NTP was carried out according to the method $\left(k_{\mathrm{A}}\right)$ of Mossé (1990) and Sriperm et al. (2011). It should be mentioned that ammonia was added to compensate the value of some less resistant amino acids that disappeared after the strong acid hydrolysis. In addition, the strong hydrolysis of the peptide bonds generates one molecule of water from each amino acid and therefore during the quantification of total amino acid one molecule of water was subtracted from each amino acid in order to get the total amino acid residue which represents the exact quantity of all amino acids (Lourenço et al. 1998; Fujihara et al. 2001).

\section{Confocal laser scanning microscopy}

Cells were observed with an SP2-AOBS confocal laserscanning microscope (Leica). The fluorochrome calcofluor white that binds to the $\beta \rightarrow 1-4$ linkages in the cell wall polysaccharides was added to the samples. Excited at $488 \mathrm{~nm}$, the cells are identified coloured in light blue.

\section{Statistical analysis}

Three experiments were conducted separately on all microalgae and their protein extract. Statistical analyses were carried out on Microsoft Excel. Measurements of three replicates for each sample were reproducible for $\pm 5 \%$ of the respective mean values.

\section{Results}

An amino acid analyser was used to obtain the amino acid profile of the crude microalgae (Table 1) and their protein extract (Table 2). The protein primary composition was reconstituted in order to find the conversion factor (Table 3) that takes into account only the protein nitrogen. The highest conversion factor evaluated for the crude biomass was 6.35 for C. vulgaris and P. cruentum and the lowest was 6.25 for $H$. pluvialis. If we compare the NTP value of the crude microalgae and the protein extract, we observe that there is no significant difference for $P$. cruentum and $A$. platensis. However, a significant difference was measured for the other three species, which correspond to green microalgae (Table 3).
Table 1 Results of total amino acids of five microalgae expressed in grams per $100 \mathrm{~g}$ of algal protein representing three replicates for three experiments $\pm \mathrm{SD}(n=3)$

\begin{tabular}{|c|c|c|c|c|c|}
\hline \multicolumn{6}{|c|}{ Crude microalgae amino acid composition } \\
\hline Amino acids & P. cruentum & A. platensis & C. vulgaris & N. oculata & H. pluvialis \\
\hline Aspartic acid & $11.21 \pm 0.45$ & $11.82 \pm 0.11$ & $10.09 \pm 0.02$ & $9.14 \pm 0.05$ & $8.85 \pm 0.10$ \\
\hline Threonine & $6.25 \pm 0.25$ & $6.16 \pm 0.10$ & $5.62 \pm 0.01$ & $5.91 \pm 0.03$ & $5.21 \pm 0.06$ \\
\hline Serine & $8.11 \pm 0.29$ & $6.85 \pm 0.02$ & $7.17 \pm 0.04$ & $6.52 \pm 0.01$ & $6.63 \pm 0.05$ \\
\hline Glutamic acid & $8.17 \pm 0.29$ & $10.50 \pm 0.09$ & $8.37 \pm 0.01$ & $10.30 \pm 0.02$ & $9.47 \pm 0.11$ \\
\hline Glycine & $6.86 \pm 0.28$ & $7.76 \pm 0.06$ & $7.93 \pm 0.01$ & $9.00 \pm 0.01$ & $9.05 \pm 0.09$ \\
\hline Alanine & $6.67 \pm 3.67$ & $9.91 \pm 0.08$ & $10.05 \pm 0.03$ & $10.92 \pm 0.01$ & $11.28 \pm 0.12$ \\
\hline Cysteine & $0.33 \pm 0.01$ & $0.18 \pm 0.02$ & $0.18 \pm 0.01$ & $0.19 \pm 0.01$ & $0.22 \pm 0.01$ \\
\hline Valine & $2.50 \pm 0.10$ & $2.86 \pm 0.02$ & $2.85 \pm 0.01$ & $3.29 \pm 0.02$ & $3.32 \pm 0.04$ \\
\hline Methionine & $2.78 \pm 0.11$ & $1.72 \pm 0.02$ & $0.60 \pm 0.01$ & $1.50 \pm 0.01$ & $0.64 \pm 0.01$ \\
\hline Isoleucine & $5.25 \pm 0.24$ & $0.12 \pm 0.01$ & $0.09 \pm 0.01$ & $0.11 \pm 0.01$ & $4.53 \pm 0.04$ \\
\hline Leucine & $5.83 \pm 0.21$ & $7.02 \pm 0.02$ & $6.91 \pm 0.02$ & $8.11 \pm 0.05$ & $8.09 \pm 0.10$ \\
\hline Tyrosine & $4.43 \pm 0.18$ & $4.83 \pm 0.05$ & $7.78 \pm 0.01$ & $3.40 \pm 0.02$ & $2.80 \pm 0.04$ \\
\hline Phenylalanine & $5.00 \pm 0.20$ & $4.82 \pm 0.04$ & $5.36 \pm 0.01$ & $5.05 \pm 0.01$ & $4.92 \pm 0.07$ \\
\hline Histidine & $1.11 \pm 0.04$ & $0.90 \pm 0.01$ & $1.16 \pm 0.01$ & $0.94 \pm 0.01$ & $0.90 \pm 0.01$ \\
\hline Lysine & $5.50 \pm 0.21$ & $5.10 \pm 0.62$ & $6.30 \pm 0.07$ & $5.70 \pm 0.01$ & $5.72 \pm 0.08$ \\
\hline Arginine & $7.78 \pm 0.29$ & $7.69 \pm 0.07$ & $6.81 \pm 0.03$ & $5.93 \pm 0.02$ & $6.10 \pm 0.08$ \\
\hline Tryptophan & $1.39 \pm 0.05$ & $1.22 \pm 0.01$ & $2.04 \pm 0.01$ & $1.24 \pm 0.01$ & $1.72 \pm 0.02$ \\
\hline Ornithine & $0.27 \pm 0.01$ & $0.16 \pm 0.09$ & $0.12 \pm 0.01$ & $0.16 \pm 0.01$ & $0.07 \pm 0.01$ \\
\hline Proline & $2.53 \pm 0.17$ & $1.95 \pm 0.05$ & $2.74 \pm 0.07$ & $4.20 \pm 0.07$ & $2.94 \pm 1.15$ \\
\hline Ammonia & $8.02 \pm 0.30$ & $8.41 \pm 0.09$ & $7.82 \pm 0.02$ & $8.38 \pm 0.08$ & $7.52 \pm 0.08$ \\
\hline
\end{tabular}


Table 2 Results of total amino acids of the protein extract extracted at $\mathrm{pH} 12$ and $40^{\circ} \mathrm{C}$ of five microalgae expressed in grams per $100 \mathrm{~g}$ of algal protein representing three replicates for three experiments $\pm \mathrm{SD}(n=3)$
Protein extract amino acid composition

\begin{tabular}{lrrrrr}
\hline Amino acids & P. cruentum & A. platensis & C. vulgaris & N. oculata & H. pluvialis \\
\hline Aspartic acid & $10.71 \pm 0.02$ & $9.70 \pm 0.02$ & $6.81 \pm 0.28$ & $4.47 \pm 0.05$ & $6.54 \pm 0.07$ \\
Threonine & $4.45 \pm 0.01$ & $5.54 \pm 0.04$ & $4.16 \pm 0.19$ & $3.18 \pm 0.04$ & $3.70 \pm 0.02$ \\
Serine & $7.49 \pm 0.02$ & $7.25 \pm 0.03$ & $5.73 \pm 0.27$ & $3.16 \pm 0.06$ & $5.66 \pm 0.01$ \\
Glutamic acid & $9.05 \pm 0.01$ & $11.65 \pm 0.02$ & $11.63 \pm 0.51$ & $22.60 \pm 0.19$ & $13.55 \pm 0.01$ \\
Glycine & $7.68 \pm 0.01$ & $8.42 \pm 0.02$ & $9.75 \pm 0.42$ & $8.79 \pm 0.10$ & $11.00 \pm 0.01$ \\
Alanine & $10.46 \pm 0.02$ & $10.94 \pm 0.02$ & $16.82 \pm 0.75$ & $14.02 \pm 0.13$ & $19.12 \pm 0.03$ \\
Cysteine & $0.27 \pm 0.01$ & $0.20 \pm 0.01$ & $0.24 \pm 0.01$ & $0.38 \pm 0.01$ & $0.40 \pm 0.01$ \\
Valine & $3.15 \pm 0.01$ & $3.31 \pm 0.01$ & $3.66 \pm 0.15$ & $2.36 \pm 0.03$ & $2.80 \pm 0.01$ \\
Methionine & $2.37 \pm 0.01$ & $1.71 \pm 0.01$ & $1.28 \pm 0.04$ & $1.23 \pm 0.03$ & $1.04 \pm 0.01$ \\
Isoleucine & $5.34 \pm 0.02$ & $0.12 \pm 0.01$ & $2.32 \pm 1.87$ & $1.08 \pm 1.44$ & $3.06 \pm 0.01$ \\
Leucine & $7.30 \pm 0.01$ & $8.02 \pm 0.02$ & $7.15 \pm 0.33$ & $4.11 \pm 0.04$ & $4.99 \pm 0.03$ \\
Tyrosine & $3.69 \pm 0.01$ & $4.33 \pm 0.01$ & $2.56 \pm 0.10$ & $2.15 \pm 0.07$ & $1.91 \pm 0.02$ \\
Phenylalanine & $4.12 \pm 0.01$ & $4.26 \pm 0.01$ & $2.74 \pm 0.12$ & $1.63 \pm 0.02$ & $2.63 \pm 0.01$ \\
Histidine & $0.79 \pm 0.03$ & $0.73 \pm 0.01$ & $0.53 \pm 0.03$ & $0.28 \pm 0.01$ & $0.43 \pm 0.01$ \\
Lysine & $5.60 \pm 0.01$ & $5.39 \pm 0.01$ & $6.16 \pm 0.27$ & $2.35 \pm 0.01$ & $3.48 \pm 0.01$ \\
Arginine & $6.63 \pm 0.02$ & $6.84 \pm 0.01$ & $5.85 \pm 2.71$ & $1.96 \pm 0.09$ & $6.88 \pm 0.01$ \\
Tryptophan & $0.72 \pm 0.02$ & $1.07 \pm 0.01$ & $0.49 \pm 0.02$ & $0.18 \pm 0.01$ & $0.31 \pm 0.01$ \\
Ornithine & $0.22 \pm 0.01$ & $0.23 \pm 0.01$ & $0.50 \pm 0.02$ & $0.55 \pm 0.03$ & $0.43 \pm 0.01$ \\
Proline & $1.87 \pm 0.02$ & $1.86 \pm 0.08$ & $2.11 \pm 0.13$ & $14.41 \pm 0.33$ & $1.61 \pm 0.04$ \\
Ammonia & $8.05 \pm 0.04$ & $8.39 \pm 0.01$ & $9.47 \pm 0.44$ & $11.09 \pm 0.31$ & $10.37 \pm 0.06$ \\
\hline & & & & &
\end{tabular}

The total nitrogen content of crude microalgae was determined by elemental analysis. The hydro-soluble proteins were quantified by the Lowry method. By using the NTP values from Table 3 , the total proteins and the corresponding fraction of hydro-soluble proteins were accurately determined starting from the results of elemental analysis (Table 4).

A small difference was observed between the essential and non-essential amino acids total percentage for $P$. cruentum, A. platensis and C. vulgaris and their protein extract, and an important difference was observed for $N$. oculata and $H$. pluvialis with a noticeable increase in non-essential

Table 3 Nitrogen-to-protein conversion factors for the crude microalgae and their protein isolate based on three replicates for three experiments $\pm \mathrm{SD}(n=3)$

\begin{tabular}{llll}
\hline NTP & & & \\
\hline Microalgae & $\begin{array}{l}\text { Crude } \\
\text { microalgae }\end{array}$ & $\begin{array}{l}\text { Protein } \\
\text { extract }\end{array}$ & $\begin{array}{l}\text { \% Relative } \\
\text { difference }\end{array}$ \\
\hline P. cruentum & $6.35 \pm 0.03$ & $6.34 \pm 0.04$ & 0.16 \\
A. platensis & $6.27 \pm 0.02$ & $6.21 \pm 0.07$ & 0.96 \\
C. vulgaris & $6.35 \pm 0.07$ & $5.96 \pm 0.23$ & 6.14 \\
N. oculata & $6.28 \pm 0.06$ & $5.86 \pm 0.32$ & 6.69 \\
H. pluvialis & $6.25 \pm 0.07$ & $5.63 \pm 0.18$ & 9.92 \\
\hline
\end{tabular}

amino acids percentage in the protein extract and a decrease in essential amino acids percentage (Table 5).

Finally, the laser scanning confocal microscopic images presented in Fig. 1 showed that in the case of $P$. cruentum and $A$. platensis a total disruption of the cell wall occurred after the alkaline treatment, whereas $C$. vulgaris, $N$. oculata and $H$. pluvialis maintained their globular form indicating that at least a part of their cell wall was intact.

\section{Discussion}

The present study contributes original individual NTP conversion factors for five current species of microalgae. Indeed, direct comparison of our results with literature values can only be done for N. oculata (Lourenço et al. 1998); the report from Gonzalez Lopez et al. (2010) combines all the cyanobacteria and $P$. cruentum in a global result. To our knowledge, NTP data for $C$. vulgaris and $H$. pluvialis have never been reported. Moreover, according to Mossé (1990), there are three kinds of NTP conversion factors called $k, k_{\mathrm{A}}$ and $k_{\mathrm{P}}$ (Yeoh and Truong 1996; Sriperm et al. 2011). In this study, $k_{\mathrm{A}}$ was calculated for all species, and this kind of conversion factor is larger than $k_{\mathrm{P}}$ and $k$. For this reason, there is a significant difference between the conversion factors calculated for $N$. oculata in this study (6.28) and the one calculated for the same microalga (4.87) in the Lourenço et al. (1998) study. 
Table 4 Different protein contents in crude microalgae

\begin{tabular}{|c|c|c|c|c|}
\hline & $\mathrm{Nea}^{\mathrm{a}}(\%)$ & Total protein $=\mathrm{Nea} \times \mathrm{NTP}^{\mathrm{b}}(\%)$ & $\begin{array}{l}\text { Hydro-soluble } \\
\text { protein }=P_{\text {Lowry }}{ }^{\mathrm{c}}(\%)\end{array}$ & $\begin{array}{l}\text { Proportion of hydro- } \\
\text { soluble protein in total } \\
\text { protein }=\frac{P_{\text {Lowy }}}{\text { Nea } \times N T P} \times 100(\%)\end{array}$ \\
\hline P. cruentum & $9.04 \pm 0.69$ & $57.33 \pm 3.84$ & $46.06 \pm 0.97$ & $80.34 \pm 1.69$ \\
\hline A. platensis & $8.53 \pm 0.20$ & $53.51 \pm 1.10$ & $37.19 \pm 2.67$ & $69.50 \pm 5.00$ \\
\hline C. vulgaris & $7.81 \pm 0.18$ & $49.59 \pm 1.04$ & $21.50 \pm 0.34$ & $43.35 \pm 0.62$ \\
\hline N. oculata & $7.41 \pm 0.39$ & $46.55 \pm 2.14$ & $15.52 \pm 0.42$ & $33.34 \pm 0.90$ \\
\hline H. pluvialis & $8.27 \pm 0.07$ & $51.73 \pm 0.43$ & $14.22 \pm 0.69$ & $27.48 \pm 1.34$ \\
\hline
\end{tabular}

${ }^{\mathrm{a}} \mathrm{Nea}$, total nitrogen \% (dw) obtained by elemental analysis

${ }^{\mathrm{b}}$ NTP, nitrogen-to-protein conversion factor from Table 3

${ }^{\mathrm{c}} P_{\text {Lowry, }}$, hydro-soluble protein $\%(\mathrm{dw})$ at $\mathrm{pH} 12$ and $40{ }^{\circ} \mathrm{C}$ calculated by Lowry method

The NTP conversion factor of the crude microalgae and their protein extract depended on the type of microalgae. If we calculate the relative difference between these two values for a single species, we observe that there is almost no difference in the case of red algae and cyanobacteria, whereas it reached almost $10 \%$ for green microalgae (Table 3 ). These differences can be correlated to the rigidity of the cell wall. Indeed, it is generally accepted that green microalgae possess a more rigid cell wall than red algae or cyanobacteria. More in detail, $P$. cruentum does not have a true cell wall but instead encapsulated by a layer of sulfurized polysaccharides (Arad et al. 1985, 1988; Adda et al. 1986; Geresh and Arad 1991; Geresh et al. 2002; Sobczuk et al. 2006). A. platensis has a relatively fragile cell wall mainly composed of murein without cellulose (Lee 2008; $\mathrm{Lu}$ et al. 2006). As far as the green microalgae, the chlorophycean $C$. vulgaris and the eustigmatophycean $N$. oculata, both have a cell wall mainly composed of cellulose and hemicelluloses (Payne and Rippingale 2000). The highest difference perceived was for $H$. pluvialis, which has a thick trilaminar cell wall composed of cellulose and sporopollenin in the aplanospore stage (MendesPinto et al. 2001; Montsant et al. 2001; Aflalo et al. 2007). The composition of its cell wall makes this microalga less permeable and extremely mechanically resistant (Hagen et al. 2002).
Taking into account the standard deviation of the three samples considered for each microalga, we could affirm that, at $95 \%$ of confidence level, all the values of total protein content shown in Table 4 are statistically equivalent. This fact is noteworthy, because when we consider the extracted hydro-soluble proteins (Table 4), we observe that their amounts decrease following the same correlation than the differences in NTP value: high extraction for the microalgae with no real cell wall and very low extraction for the most rigid of all. Therefore, the hydro-soluble protein capable to be extracted under alkaline conditions from inside the cell is correlated to the cell wall characteristics and to the freeze-drying process that conserves well the samples but it makes the protein extraction more difficult for some algal species. In addition, the high values of hydro-soluble proteins extracted especially for $P$. cruentum and $A$. platensis could be explained by the possible presence of peptides and free amino acids because no precipitation was carried out (Nguyen and Harvey 1994; Barbarino and Lourenço 2005).

Further evidence was found in the variation in composition relative to essential and non-essential amino acids (Table 5) in the protein extract of the green microalgae. There was a significant drop in the percentage of essential amino acids ranging from $13.9 \%$ for C. vulgaris to $49.1 \%$
Table 5 Percentage (dw) of essential and non-essential amino acids for each microalga and its protein extract

\begin{tabular}{lccccccc}
\hline & \multicolumn{3}{l}{ Crude microalgae } & & \multicolumn{2}{l}{ Protein extract } \\
\cline { 2 - 3 } & Essential & Non-essential & Not identified & & Essential & Non-essential & \multirow{2}{*}{ Not identified } \\
\hline P. cruentum & 46.81 & 44.89 & 8.29 & & 44.58 & 47.15 & 8.27 \\
A. platensis & 41.76 & 49.67 & 8.57 & & 39.87 & 51.50 & 8.62 \\
C. vulgaris & 41.02 & 51.03 & 7.94 & & 35.32 & 54.70 & 9.97 \\
N. oculata & 41.00 & 50.46 & 8.53 & & 20.88 & 67.47 & 11.64 \\
H. pluvialis & 43.91 & 48.50 & 7.58 & & 29.01 & 60.17 & 10.81 \\
\hline
\end{tabular}



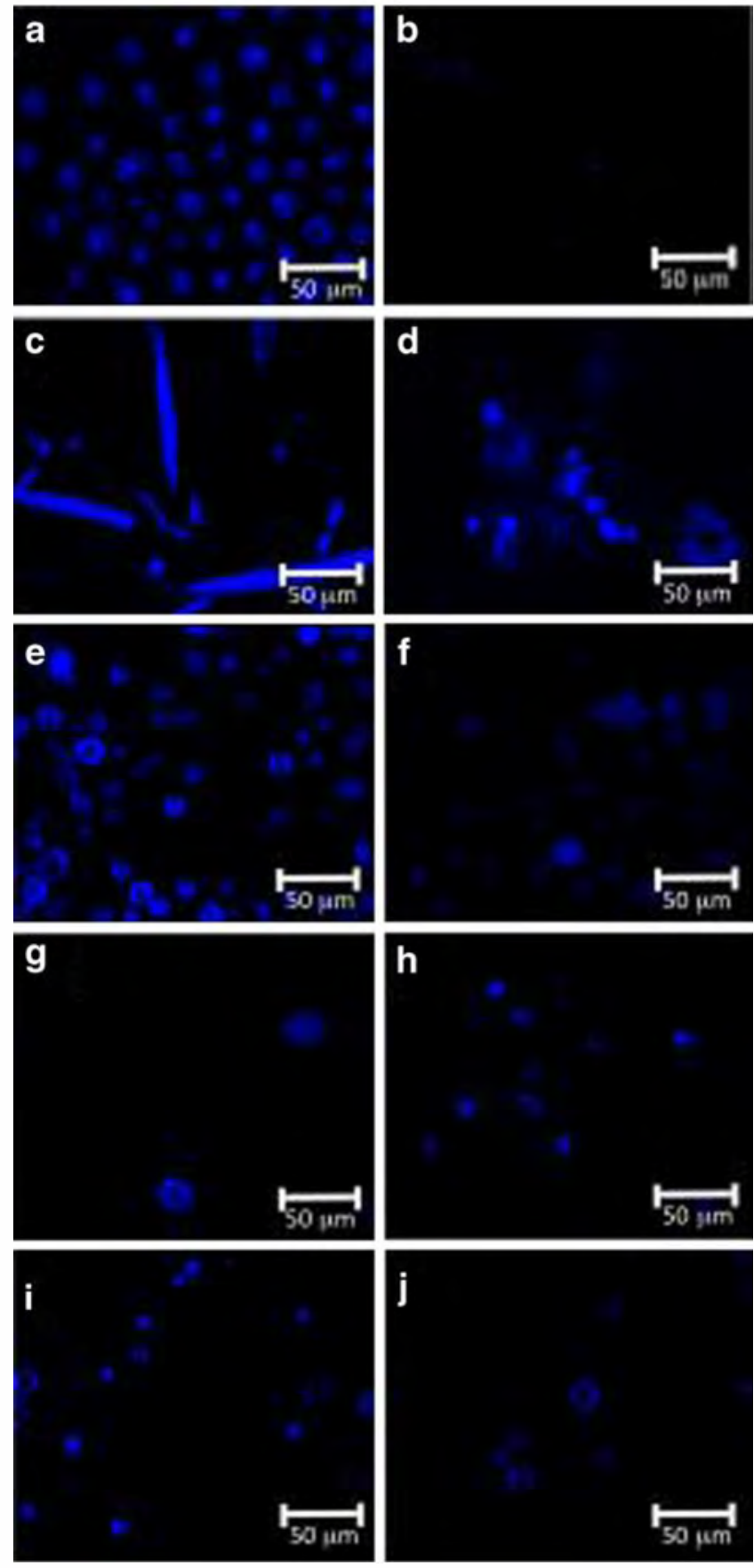

Fig. 1 Laser scanning confocal microscopic observation before (left) and after (right) alkaline treatment for each microalga. a and b $P$. cruentum, $\mathbf{c}$ and $\mathbf{d}$ A. platensis, $\mathbf{e}$ and $\mathbf{f} C$. vulgaris, $\mathbf{g}$ and $\mathbf{h} N$. oculata, $\mathbf{i}$ and $\mathbf{j}$ H. pluvialis

for $N$. oculata and an increase in non-essential amino acids from $6.7 \%$ for the former to $25.2 \%$ for the latter. On the contrary, only small changes in the composition of the proteins were detected for fragile cell wall microalgae, with a percentage difference ranging from $4.5 \%$ for $A$. platensis to $4.8 \%$ for the essential amino acids of $P$. cruentum, whereas non-essential amino acids difference ranged from $3.5 \%$ for the former to $4.8 \%$ for the latter.

These correlations with the relative hardness of the cell wall can integrate a chemical dimension as well. Indeed, the sporopollenin contained in the most rigid cell wall $(H$. pluvialis) is known to be extremely resistant to chemical agents (Hagen et al. 2002). But in the case of cellulose-rich cell walls, such as $C$. vulgaris and $N$. oculata, the sodium hydroxide is able to penetrate the microcrystalline structure of cellulose to form alcoholates in a process similar to mercerisation. Sodium hydroxide can also dissolve the hemicelluloses attached to cellulose. The partial permeation of this kind of cell wall can therefore occur by alkaline action. Finally, A. platensis has a cell wall rich in amino sugars cross-linked with oligopeptide chains. The former are labile in alkaline conditions by deamidation of the $\mathrm{N}$-acetylglucosamine and the latter are soluble in alkaline conditions. The cell wall becomes therefore very permeable allowing the alkaline extraction of proteins. In summary, the chemical action acts in synergy with the mechanical characteristics of the cell wall.

Extraction of proteins together with the evaluation of the conversion factor brought additional evidence that the cell wall of any microalga plays an important role in protein quantification. This means that not taking it into consideration may lead to wrong quantification of the protein content. In addition, for microalgae, there is not a universal conversion factor that can be recommended for all species as demonstrated by comparison of our study with many studies which have been carried out on dozens of different microalgae. Therefore, every time accurate quantification of protein is needed, it will be required to evaluate the conversion factor. In addition, this study showed a correlation between the cell wall rigidity and/or the chemical structure and the differences in NTP conversion value. Microalgae with fragile cell wall did not show significant differences with their protein extract, which was the complete opposite for the microalgae having a rigid cell wall that showed noticeable difference on evaluating the conversion factor of their protein extract, and therefore, breaking or permeabilize the rigid cell wall of $C$. vulgaris, $N$. oculata and $H$. pluvialis is strongly required to prevent underestimation of the protein content after extraction. Logically, there is no need for cell wall breaking for $P$. cruentum since it does not have a cell wall and concerning $A$. platensis soft cell wall disruption technique is needed to make sure that its fragile cell wall will not hinder the extraction of any intracellular components.

Acknowledgments The authors would like to thank Alpha Biotech for providing the biomass and also we are thankful to Dr Philippe Michaud, Dr Celine Laroche, Mr Jean-François Fabre and Mrs Cécile Pouzet for their support and expertise. This work was supported by the French National Research Agency (ANR) in the context of Algoraffinerie project. 


\section{References}

Adda M, Merchuk JC, Arad S (1986) Effect of nitrate on growth and production of cell-wall polysaccharide by the unicellular red alga Porphyridium. Biomass 10:131-140

Aflalo C, Meshulam Y, Zarka A, Boussiba S (2007) On the relative efficiency of two- vs. one-stage production of astaxanthin by the green alga Haematococcus pluvialis. Biotechnol Bioeng 98:300-305

Arad S, Adda M, Cohen E (1985) The potential of production of sulfated polysaccharides from Porphyridium. Plant Soil 89:117-127

Arad S, Friedman O, Rotem A (1988) Effect of nitrogen on polysaccharide production in a Porphyridium sp. Appl Environ Microbiol 54:2411-2414

Barbarino E, Lourenço SO (2005) An evaluation of methodologies for extraction and quantification of protein of marine macro-and microalgae. J Appl Phycol 17:447-460

Becker EW (1994) Microalgae biotechnology and microbiology. Cambridge University Press, Cambridge

Crossman DJ, Clements KD, Cooper GJS (2000) Determination of protein for studies of marine herbivory: a comparison of methods. J Exp Mar Biol Ecol 244:45-65

Diniz GS, Barbanino E, Oiano-Neto J, Pacheco S, Lourenço SO (2011) Gross chemical profile and calculation of nitrogen-to-protein conversion factors for five tropical seaweeds. Am J Plant Sci 2:287-296

Fradique M, Batista AP, Nunes MC, Gouveia L, Bandarra NM, Raymundo A (2010) Incorporation of Chlorella vulgaris and Spirulina maxima biomass in pasta products. Part 1: preparation and evaluation. J Sci Food Agric 90:1656-1664

Fujihara S, Kasuga A, Aoyagi Y (2001) Nitrogen-to-protein conversion factors for common vegetables in Japan. J Food Sci 66:412-415

Geresh S, Arad S (1991) The extracellular polysaccharides of the red microalgae: chemistry and rheology. Bioresour Technol 38:195-201

Geresh S, Mamontov A, Weinstein J (2002) Sulfation of extracellular polysaccharides of red microalgae: preparation, characterization and properties. J Biochem Biophys Meth 50:179-187

Gonzalez Lopez CV, García MDCC, Fernandez FGA, Bustos CS, Chisti Y, Sevilla JMF (2010) Protein measurements of microalgal and cyanobacterial biomass. Bioresour Technol 101:7587-7591

Hagen C, Siegmund S, Braune W (2002) Ultrastructure and chemical changes in the cell wall of Haematococcus pluvialis (Volvocales, Chlorophyta) during aplanospore formation. Eur J Phycol 37:217226

Lee RE (2008) Phycology. Cambridge University Press, Cambridge

Loubiere K, Pruvost J, Aloui F, Legrand J (2011) Investigations in an external-loop airlift photobioreactor with annular light chambers and swirling flow. Chem Eng Res Des 89:164-171

Lourenço SO, Barbarino E, Marquez UML, Aidar E (1998) Distribution of intracellular nitrogen in marine microalgae: basis for the calculation of specific nitrogen-to-protein conversion factors. $\mathrm{J}$ Phycol 34:798-811
Lourenço SO, Barbarino E, De-Paula JC, Pereira LODS, Marquez UML (2002) Amino acid composition, protein content and calculation of nitrogen-to-protein conversion factors for 19 tropical seaweeds. Phycol Res 50:233-241

Lourenço SO, Barbarino E, Lavan PL, Lanfer Marquez UM, Aidar E (2004) Distribution of intracellular nitrogen in marine microalgae: calculation of new nitrogen-to-protein conversion factors. Eur $\mathbf{J}$ Phycol 39:17-32

Lowry OH, Rosebrough NJ, Farr AL, Randall RJ (1951) Protein measurement with the Folin phenol reagent. J Biol Chem 193:265275

Lu HK, Hsieh CC, Hsu JJ, Yang YK, Chou HN (2006) Preventive effects of Spirulina platensis on skeletal muscle damage under exercise-induced oxidative stress. Eur J Appl Physiol 98:220-226

Mendes-Pinto MM, Raposo MFJ, Bowen J, Young AJ, Morais R (2001) Evaluation of different cell disruption processes on encysted cells of Haematococcus pluvialis: effects on astaxanthin recovery and implications for bioavailability. J Appl Phycol 13:19-24

Montsant A, Zarka A, Boussiba S (2001) Presence of a nonhydrolyzable biopolymer in the cell wall of vegetative cells and astaxanthin-rich cysts of Haematococcus pluvialis (Chlorophyceae). Mar Biotechnol 3:515-521

Moore S, Stein WH (1948) Photometric ninhydrin method for use in the chromatography of amino acids. J Biol Chem 176:367-388

Mossé J (1990) Nitrogen-to-protein conversion factor for ten cereals and six legumes or oilseeds. A reappraisal of its definition and determination. Variation according to species and to seed protein content. J Agric Food Chem 38:18-24

Nguyen RT, Harvey HR (1994) A rapid micro-scale method for the extraction and analysis of protein in marine samples. Mar Chem 45:1-14

Payne MF, Rippingale RJ (2000) Evaluation of diets for culture of the calanoid copepod Gladioferens imparipes. Aquaculture 187:8596

Peterson GL (1979) Review of the Folin phenol protein quantitation method of Lowry, Rosebrough, Farr and Randall. Anal Biochem 100:201-220

Sobczuk T, Camacho F, Grima E, Chisti Y (2006) Effects of agitation on the microalgae Phaeodactylum tricornutum and Porphyridium cruentum. Bioproc Biosys Eng 28:243-250

Sriperm N, Pesti GM, Tillman PB (2011) Evaluation of the fixed nitrogen-to-protein $(\mathrm{N}: \mathrm{P})$ conversion factor $(6.25)$ versus ingredient specific N:P conversion factors in feedstuffs. J Sci Food Agric 91:1182-1186

Vonshak A (1997) Spirulina platensis (Arthrospira). Physiology, cellbiology and biotechnology. Taylor and Francis, London

Yeoh HH, Truong VD (1996) Protein contents, amino acid compositions and nitrogen-to-protein conversion factors for cassava roots. J Sci Food Agric 70:51-54 